\title{
DETECÇÃO DE BEGOMOVIRUS EM MARACUJAZEIRO (Passiflora edulis Sims) NO ESTADO DE ALAGOAS ${ }^{1}$
}

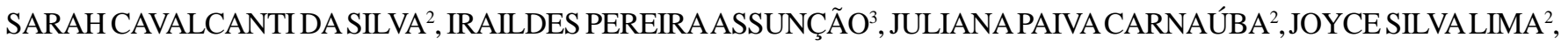 \\ EDNA PEIXOTO DA ROCHA AMORIM ${ }^{4}$, GAUS DE ANDRADE LIMA ${ }^{5}$
}

\begin{abstract}
RESUMO - O maracujazeiro é uma cultura de grande importância econômica nos países tropicais, destacando-se o Brasil como o maior produtor. No presente trabalho, é relatada a infecção de plantas de maracujazeiro por um vírus do gênero Begomovirus, família Geminiviridae, no município de Anadia, Estado de Alagoas. As plantas infectadas apresentavam sintomas de mosaico amarelo, redução drástica de crescimento e da área foliar. DNA extraído de plantas sintomáticas foi empregado como molde em PCRs, contendo os pares de primers PAL1v1978 e par1C496 ou PBL1v2040 e PCRc1 que direcionam, respectivamente, a amplificação de regiões de aproximadamente 1,2 kb do DNA-A e 0,6 kb do DNA-B, do genoma dos begomovírus. Fragmentos de tamanho esperado foram amplificados a partir de amostras de plantas sintomáticas, confirmando a infecção por Begomovirus. O seqüenciamento desses fragmentos está em andamento para uma definição precisa da espécie viral.
\end{abstract}

Termos para indexação: Geminividae, diagnose, PCR.

\section{Begomovirus DETECTION IN PASSION FRUIT (Passiflora edulis Sims) IN THE STATE OF ALAGOAS, BRAZIL}

\begin{abstract}
Passion fruit is a crop of great economic importance in Tropical countries, distinguishing Brazil as the greatest producer. The present work reports the infection of passion fruit by a virus belonging to the genus Begomovirus, family Geminiviridae in the state of Alagoas, Brazil. Infected plants showed symptoms of yellow mosaic, drastic reduction of growth and leaf area. The DNA extracted from symptomatic plants was used as template in PCR's, containing the pairs of primers PAL1v1978 and par1C496 or PBL1v2040 and PCRc1, which direct the amplification of regions of approximately $1.2 \mathrm{~kb}$ DNA-A and $0.6 \mathrm{~kb}$ DNA-B, from begomovírus genome, respectively. Fragments of the components A and B with expected size were amplified from samples of symptomatic plants, confirming the infection by a begomovírus.
\end{abstract}

Index terms: Geminiviridae, diagnosis, PCR.

O maracujazeiro (Passiflora edulis Sims) é uma cultura típica de países tropicais, os quais são responsáveis por aproximadamente $90 \%$ da produção mundial, destacando-se o Brasil como o maior produtor. No ano de 2000, a área colhida no Brasil foi de 33,4 mil hectares, tendo como os maiores produtores os Estados da Bahia, São Paulo, Sergipe, Minas Gerais, Goiás, Espírito Santo, Ceará, Pará, Rio de Janeiro e Alagoas (Agrianual, 2004). O Estado de Alagoas conta atualmente com 1.329 ha cultivados com maracujá, com produção anual de 7.561 t. (IBGE, 2002). Entretanto, a ocorrência de doenças pode dificultar o cultivo e causar reduções na produção dessa cultura. Entre as doenças importantes, estão as viroses, destacando-se como mais freqüente e mais destrutiva aquela causada pelo vírus do endurecimento dos frutos (Passion fruit woodiness virus - PWV, Potyvirus) (Novaes et al., 2002).

No ano de 2002, Novaes et al. (2002) relataram a ocorrência de um begomovírus causando infecção de maracujazeiros no Estado da Bahia, sendo esse o primeiro registro da doença no Brasil. Após seqüenciamento de parte do DNA-A desse begomovírus, Novaes et al. (2003) sugeriram tratar-se de uma possível nova espécie, propondo o nome Passion flower little leaf mosaic virus. Infecção de maracujazeiro por begomovírus já havia sido relatada em Porto Rico (Brown et al., 1993).

Em maio de 2005, foram observadas, em duas propriedades no município de Anadia-AL, algumas plantas de maracujá com sintomas típicos de infecção por geminivírus, ou seja, mosaico amarelo, redução de crescimento e encarquilhamento do limbo foliar. Observou-se também a presença de mosca-branca (Bemisia tabaci Gennadius) nas plantas infectadas. O objetivo do presente trabalho foi determinar a etiologia dessa doença no Estado de Alagoas. As plantas foram coletadas e posteriormente procedeu-se a extração do DNA total (DNA vegetal e DNA viral) de plantas sintomáticas e assintomáticas, utilizando-se do protocolo descrito por Ferreira \& Grattapaglia (1996).

Amostras do DNA extraído de plantas sintomáticas foram utilizadas para confirmar a infecção por geminivírus por meio da amplificação de fragmentos do genoma viral via PCR. Foram utilizados os oligonucleotídeos PAL1v1978 e PAR1c496, específicos para o componente A, e PBL1v2040 e PCRc1, específicos para o componente B (Rojas et al., 1993), dos begomovírus bipartidos. Esses oligonucleotídeos direcionaram a amplificação de um fragmento com aproximadamente 1.200 nucleotídeos para o componente A, compreendendo as extremidades 5' dos genes Rep e $C p$ e toda região comum, e de cerca de 550 nucleotídeos para o componente B, a extremidade 5' do gene $N s$ e a região comum. Como controle negativo, foram utilizadas alíquotas de DNA extraído de plantas sadias de maracujá e, como controles positivos, clones contendo fragmentos do genoma de um begomovírus previamente caracterizado (Lima et al., 2002).

Nas amostras provenientes de plantas sintomáticas, bem como nos controles positivos, foram observados produtos de amplificação de tamanho esperado, enquanto nenhum produto de amplificação foi observado nas reações contendo DNA extraído de plantas sadias (Fig. 1). Os oligonucleotídeos utilizados são degenerados em muitas posições e têm sido considerados universais para a detecção de begomovírus em vários tecidos de plantas, assim como no inseto vetor (Rojas et al., 1993; Lima et al., 2002). O seqüenciamento do genoma desse begomovírus está em andamento visando à elucidação de sua espécie.

\footnotetext{
${ }^{1}$ (Trabalho 186-2005). Recebido: 22-11-2005. Aceito para publicação: 24-07-2006.

${ }^{2}$ Mestranda em Agronomia - Produção Vegetal, CECA/UFAL. BR 104, km 85, Rio Largo, Alagoas, CEP. 57100-000

${ }^{3}$ Engenheira Agrônoma, bolsista de Pós-doutorado PRODOC/CAPES. E-mail: i_assuncao@ @otmail.com

${ }^{4}$ Engenheira Agrônoma, Doutora em Fitopatologia, CECA/UFAL. E-mail: epra@ $@$ fapeal.br

${ }^{5}$ Engenheiro Agrônomo, Doutor em Fitopatologia, CCBi/UFAL. E-mail: gausandrade@yahoo.com.br
} 


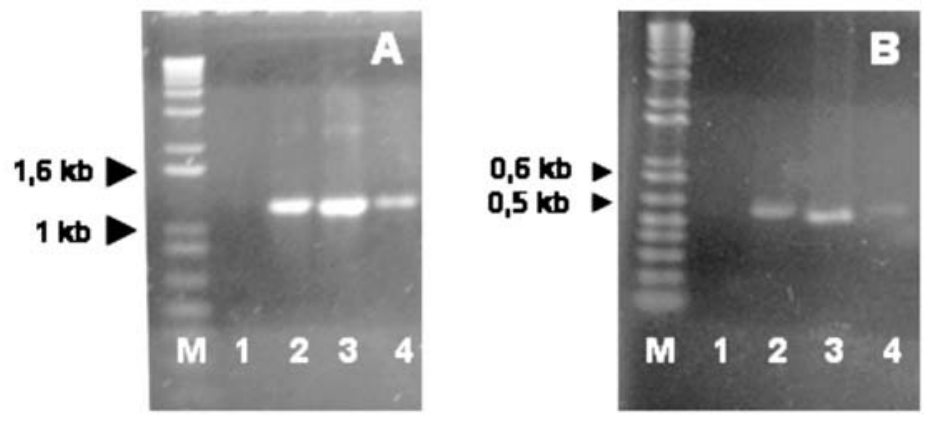

FIGURA 1 - Produtos de PCR amplificados a partir dos componentes DNA-A (A) e DNA-B (B) de begomovírus. $\mathrm{M}=1 \mathrm{~Kb}$ DNA Plus Ladder; 1 = controle negativo $; 2=$ controle positivo, 3 e 4 plantas infectadas.

\section{REFERÊNCIAS}

AGRIANUAL: anuário de agricultura brasileira. São Paulo: FNP Consultoria e Comércio, 2004. 409p.

BROWN, J.K.; BIRD, J.; FLETCHER, D.C. First report of passiflora leaf mottle disease caused by a whitefly-transmitted geminivirus in Puerto Rico. Plant Disease, Saint Paul, v.77, p.1.264, 1993.
FERREIRA, M.E.; GRATTAPAGLIA, D. Introdução ao Uso de Marcadores Moleculares em Análise Genética. 2.ed. Brasília: EMBRAPA-CENARGEN, 1996. 220p.

IBGE. Produção Agrícola Municipal: culturas temporárias e permanentes, Rio de Janeiro, 2002. v.29, p.1-88.

LIMA, G.S.A.; ASSUNÇÃO, I.P.; RESENDE, L.V.; FERREIRA, M.A.J.; VIANA, T.H.P.; GALLINDO, F.A.T.; FREITAS, N.S. Detecção de begomovírus associados a plantas invasoras no Estado de Pernambuco e caracterização molecular parcial de um isolado de Sida rhombifolia. Summa Phytopathologica, Botucatu, v.28, p.353-356, 2002.

NOVAES, Q.S.; FREITAS-ASTUA, J.; YUKI, V.A.; KITAJIMA, E.W.; CAMARGO, L.E.A.; REZENDE, J.A.M. Partial characterization of a bipartite begomovirus infecting yellow passion flower in Brazil. Plant Pathology, Berlin, v.52, p.648-654, 2003

NOVAES, Q.S.; FREITAS-ASTUA, J.; SÃO JOSÉ, A.R.; YUKI, V.A.; KITAJIMA, E.W.; REZENDE, J.A.M. Infecção mista de maracujazeiro com o Passion fruit woodiness virus e um begomovírus no Estado da Bahia. Fitopatologia Brasileira, Brasília, v. 27, p.648, 2002.

ROJAS, M.R.; GILBERTSON, R.L.; RUSSELL, D.R.; MAXWELL, D.P. Use of degenerate primers in the polimerase chain reaction to detect whitefly-transmitted geminivirus. Plant Disease, Saint Paul, v.77, p.340-347, 1993. 